\title{
Experimental Investigation on Ethanol-Petrol Blends Operating with a Petrol Engine: An Overview
}

\author{
Nazrul Atan ${ }^{1,2, a}$, Azizul Mokhtar ${ }^{1,2}$, Najib Rahman ${ }^{1,2}$, Amir Khalid $^{2, b}$ \\ ${ }^{1}$ Kolej Kemahiran Tinggi Mara Kuantan, KM 8, Jalan Gambang, 25150 Kuantan, Pahang, Malaysia \\ ${ }^{2}$ Combustion Research Group (CRG), Centre for Energy and Industrial Environment Studies \\ (CEIES), UniversitiTun Hussein Onn Malaysia,Parit Raja, BatuPahat, 86400 Johor, Malaysia. \\ anazrul@kktmkuantan.edu.my, bamirk@uthm.edu.my
}

Keywords: biopetrol, petrol engine, performance, emissions, biopetrol fuel properties

\begin{abstract}
The use of biopetrol fuel as alternative fuels in gasoline engine has been around for many years and Ethanol-petrol has the potential to be used as alternative fuel that can reduce the total $\mathrm{CO}_{2}$ emission from internal petrol engine. However, the changes of bio-petrol is a very complex and need further understanding for researchers due to the relevance of the increase in the petroleum price and the future environmental regulation. This review paper focuses to ascertain a new approach in potential on ethanol-petrol blends operating with a petrol engine especially the effects of ethanol gas petrol blending ratio and variant types of ethanol on performance and emissions of petrol engine. It is shown that the variant in biopetrol blending ratio and engine operational condition are reduced engine-out emissions and increased efficiency. This paper presents on a review on three different types of ethanol like sugar cane, wheat and corn with various blended rates. Investigation framework study on how to complete the research is also included in this paper.
\end{abstract}

\section{Introduction}

Today the petroleum stockpiles are limited and will ultimately run out. The ascension of population and urbanization makes the demand of energy is increasing daily. As the major typical energy sources like coal, petroleum, and fossil fuel square measure step by step depleted, biomass is rising collectively of the promising environmentally friendly renewable energy choices [1-3]. Bio-fuel initiative has been backed by government policies within the search energy security through partly replacing the restricted fossil fuels and reducing threat to the surroundings from exhaust emissions and warming. The main fuel found to be associate progressively vital various to crude is bio-fuel. Bio-fuel conjointly produces less greenhouse gases like carbonic acid gas. Once either bio-fuel or crude oil is burned, the carbon content of the fuel returns to the atmosphere as carbonic acid gas [46]. Many researchers have according on ethanol/gasoline blends engine performance and emissions characteristics. The advantages of biofuels are simply offered from common biomass sources, carbon oxide cycle happens in combustion, they're terribly environmentally friendly, and they're perishable and contribute to property [7-8]. This review paper aims to study the run engine with different percentage of blending of gasoline and ethanol to reduce the exhaust emissions and also to increase efficiency of the engine.

\section{Effects of bio-ethanol in petrol engine.}

Table 1 shows the properties of ethanol-unleaded gasoline blended fuels. The test fuels were gasoline (E0) and gasoline ethanol blends E10, E20, E40 and E60, the numbers following E indicate percentage of volumetric amount of ethanol. The experiments were performed at six completely different compression ratios starting from 8:1 to 13:1 for every fuel and therefore the result of engine performance was investigated. The purity ratio of ethanol is $99.5 \%$ [9]. The initial tests were conducted using low ethanol blends (up to $30 \%$ ethanol in volume) to identify suitable injection strategies, involving both single and split injections respectively. The single injection ways enclosed commonplace early homogenized and late (compression stroke) injections. Two different split injection strategies were investigated. For these the first injection occurred just after intake 
valve opening (IVO), with the second injection occurring either before or after intake valve closing (IVC). The two injection strategies chosen were the single homogeneous injection and the split injection where the second injection occurred after EVC, these are summarized in Table 2 along with the spark timings and fuel blends used for this study [10].

Table 1: Properties of ethanol-unleaded gasoline blended fuels (E0, E10, E20, E40 and E 60) [9]

\begin{tabular}{|c|c|c|c|c|c|c|}
\hline \multirow[t]{2}{*}{ Property item } & \multirow[t]{2}{*}{ Method } & \multicolumn{5}{|c|}{ Test fuels } \\
\hline & & E0 & E10 & E20 & $\mathrm{E} 40$ & E60 \\
\hline \multicolumn{7}{|l|}{ Distillation (vol\%) } \\
\hline $70^{\circ} \mathrm{C}$ & ASTM D 86 & 24 & 40.2 & 39.3 & 37.7 & 18.2 \\
\hline $100^{\circ} \mathrm{C}$ & & 46.8 & 53.9 & 66 & 84.2 & 92.5 \\
\hline $180^{\circ} \mathrm{C}$ & & 97.6 & 97.3 & 98 & 98.2 & 98.7 \\
\hline Density $\left(\mathrm{kg} / \mathrm{m}^{3}\right.$ at $\left.15^{\circ} \mathrm{C}\right)$ & ASTM D 1298 & 764.9 & 768 & 771.5 & 780.6 & 789.5 \\
\hline $\mathrm{RVP}(\mathrm{kPa})$ & ASTM D 323 & 57.6 & 66.7 & 66.2 & 63 & 57.4 \\
\hline Lead content $(\mathrm{g} / \mathrm{L})$ & ASTM D 3237 & 0.004 & 0.003 & 0.002 & 0 & 0 \\
\hline Sulfur $(w t / \%)$ & ASTM D 5453 & 0.012 & 0.017 & 0.022 & 0.026 & 0.032 \\
\hline Stoichiometric air-fuel ratio (weight) ${ }^{a}$ & & 14.7 & 14,13 & 13.56 & 12.42 & 11.28 \\
\hline Lower heating value $(\mathrm{kJ} / \mathrm{kg})^{\mathrm{a}}$ & & 43,932 & 42,185 & 40,430 & 36,870 & 33,400 \\
\hline RON & ASTM D 2699 & 86.4 & 87.4 & 89.8 & 90.9 & 92.7 \\
\hline MON & ASTM D 2700 & 98.8 & 99.9 & 101.6 & 101.7 & 102.8 \\
\hline
\end{tabular}

${ }^{a}$ Typical or calculated values.

Table 2: Test conditions [10]

\begin{tabular}{|c|c|c|c|}
\hline $\begin{array}{l}\text { Fuel blends (\% } \%_{\text {Vol. }} \text { ethanol) } \\
\text { Spark timing ( }{ }^{\circ} \text { TTDC) }\end{array}$ & $\begin{array}{l}0,10,20,30,50,8 \\
19,24,29,34^{4}, 39\end{array}$ & , 100 & \\
\hline Injection strategies & $\begin{array}{l}\text { No. of injections } \\
\text { Single } \\
\text { Double }^{b}\end{array}$ & $\begin{array}{l}\text { Sol ("bTDC) } \\
280 \\
\text { 1st } 371 \\
\text { 2nd } 141\end{array}$ & $\begin{array}{l}\text { Designation } \\
280 \\
371 / 141\end{array}$ \\
\hline Stoichiometry & $i=1$ & & \\
\hline Engine speed (rpm) & 1500 & & \\
\hline IMEP (bar) & 3.4 & & \\
\hline
\end{tabular}

\section{Effects of bio-ethanol in performance engine.}

Experimental apparatus included three major systems, i.e. the engine system, the power measurement system, and the exhaust measurement system shown in Figure 1. The engine system used in this experiment was a commercial engine. The engine output power was metered by the hydraulic dynamometer made by Taylan Etker. In the experiments, the concentrations of $\mathrm{CO}, \mathrm{CO} 2$, $\mathrm{HC}$ and $\mathrm{O} 2$ in the exhaust gas were measured on-line by the analyzer of VLT-3600 with pre calibration [11-12].

Figure 2 presents the mean power output versus loads for various 190 proof ethanol/gasoline blends. The engine power output decrease at low loads by $84 \%, 94 \%, 54 \%$ and $38 \%$ for E10, E15, E20 and E25 respectively, comparing with gasoline while at high loads by $89 \%, 96 \%, 56 \%$ and $41 \%$ for E10, E15, E20 and E25, respectively. In general the engine power output decreased by $86.5 \%, 95 \%, 55 \%$ and $36.5 \%$ at E10, E15, E20 and E25, respectively, comparing with gasoline. The higher power output of the blends can be attributed to the greater volume of blends being carbureted at the same load [13-14]. 


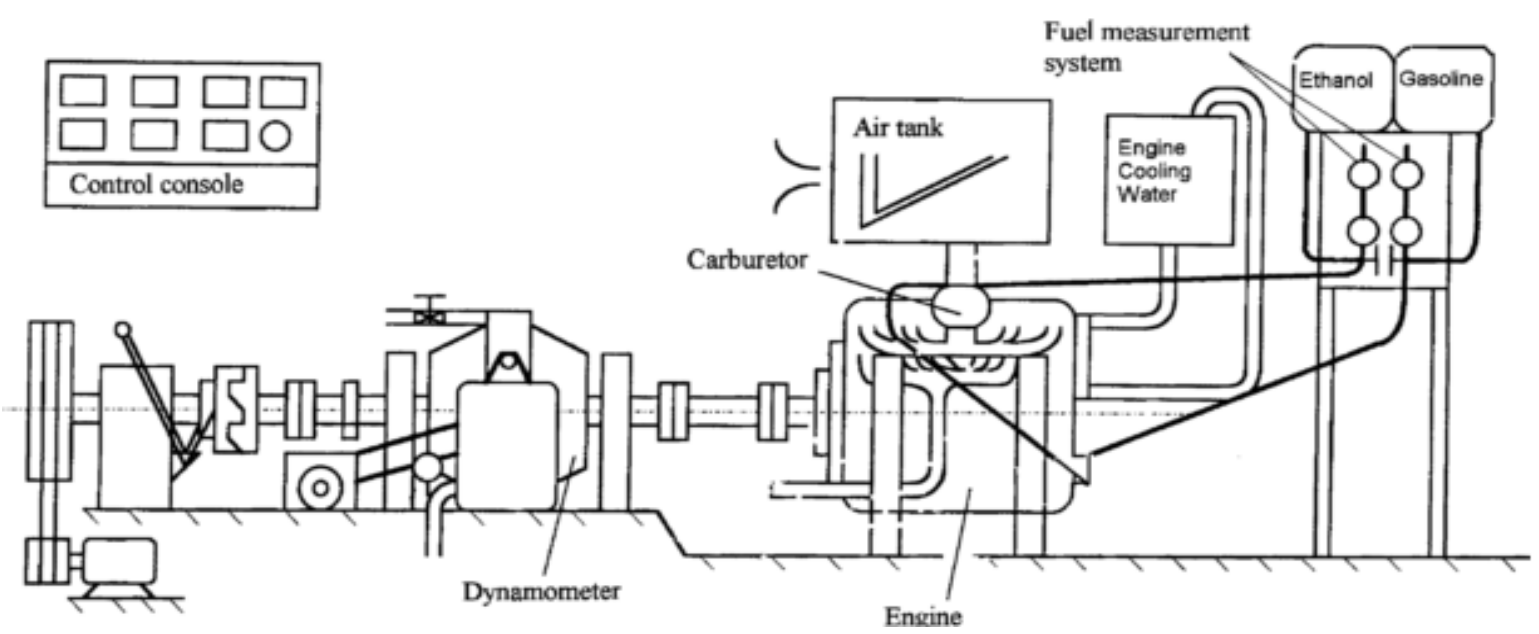

Figure 1: Schematic diagram of the experimental system [11].

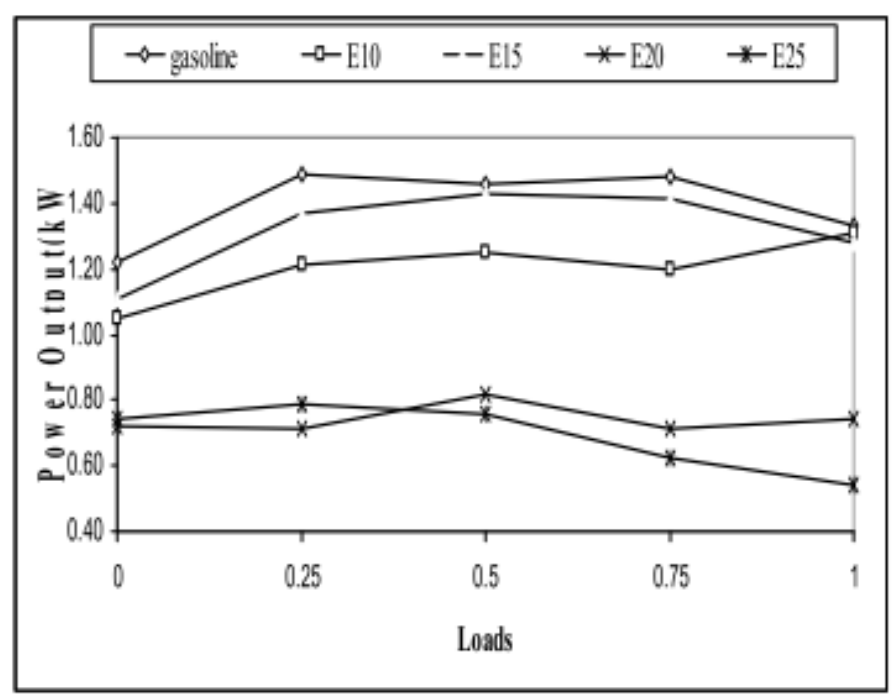

Figure 2: The effect of ethanol on Performance [13]

\section{Influences of emission regulation bio-ethanol.}

Figure 3 show the effect of the $\mathrm{E} \%$ in the fuel blend on the $\mathrm{CO}, \mathrm{CO}_{2}$ and $\mathrm{HC}$. For the $\mathrm{x}$-axis show the ethanol (\%) and the $\mathrm{y}$-axis show the fuel blend (\%). From Figure 7, it can be seen that as the E\% increases to $20 \%$, the $\mathrm{CO}$ and $\mathrm{HC}$ concentrations decrease and then increases for all engine speeds. The $\mathrm{CO}_{2}$ concentrations have an opposite behavior when compared to the $\mathrm{CO}$ concentrations, and this is clear in carbon monoxide and carbon dioxide. This is due to improving the combustion process as a result of the oxygen content in the ethanol fuel [15-16]. 

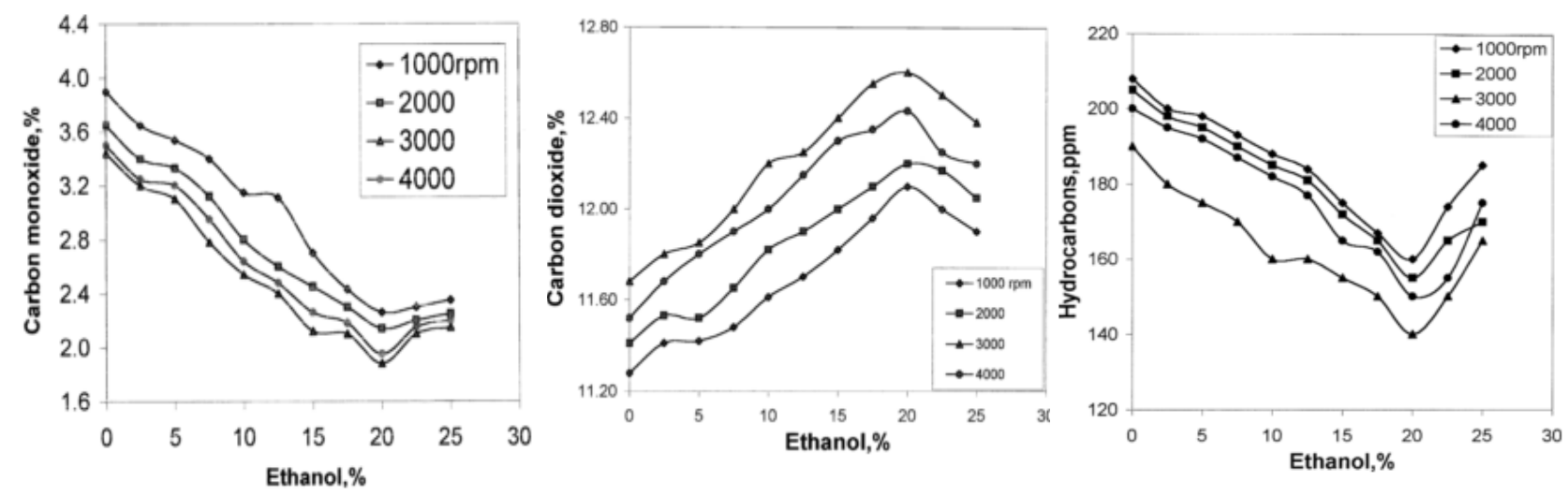

Figure 3: The effect of ethanol addition on $\mathrm{CO}, \mathrm{CO}_{2}$ and $\mathrm{HC}$ emission [15]

\section{Conclusion}

In this present review paper, the aim is to using bio petrol in petrol engine and Ethanol-petrol has the potential to be used as alternative fuel that can reduce the emission and increase performance petrol engine. There are many researchers done their studied (experiment) about bio-ethanol blend use, that make the engine power and fuel consumption of the engine slightly increase.

\section{Acknowledgement}

The authors also would like to thank the Ministry of Higher Education Malaysia for supporting this research under the Fundamental Research Grant Scheme (FRGS) vot.1054.

\section{References}

[1] A. Demirbas, Biodiesel: A Realistic Fuel Alternative for Diesel Engines: Springer, 2008.

[2] Pukalskas, S., \& Grabys, J. (2006). Influence of composition of gasoline - ethanol, 10, 3-4.

[3] Amir Khalid, M.D. Anuar, Yusri Ishak, B. Manshoor, Azwan Sapit, Mutalib Leman, Izzuddin Zaman, "Emissions characteristics of small diesel engine fuelled by waste cooking oil", MATEC Web of Conferences, Volume 13, 2014, Article number 06006, DOI: $10.1051 /$ matecconf $/ 20141306006$.

[4] Kheiralla, A., El-Awad, M., \& Hassan, M. Experimental Determination of Fuel Properties of Ethanol/Gasoline Blends as Bio-fuel for SI engine. International Conference on Mechanical, Automobile and Robotics Engineering (ICMAR'2012) Penang. Malaysia (2012).

[5] Amir Khalid, Keisuke Hayashi, Yoshiyuki Kidoguchi, Tomoaki Yatsufusa, "Effect of air entrainment and oxygen concentration on endothermic and heat recovery process of diesel ignition”, (2011) SAE Technical Papers, DOI: 10.4271/2011-01-1834.

[6] Amir Khalid, Norazwan Azman, Hanis Zakaria, B. Manshoor, Izzuddin Zaman, Azwan Sapit, Mutalib Leman, "Effects of storage duration on biodiesel properties derived from waste cooking oil", Applied Mechanics and Materials, Volume 554, 2014, Pages 494-499, DOI: 10.4028/www.scientific.net/AMM.554.494.

[7] Puppan, D., Environmental evaluation of biofuels. Periodica Polytechnica Ser Soc Man Sci 10:95-116.,(2002).

[8] Amir Khalid, N.Tamaldin, M. Jaat, M. F. M. Ali, B. Manshoor, Izzuddin Zaman, "Impacts of biodiesel storage duration on fuel properties and emissions", Procedia Engineering, volume 68, 2013, Pages 225 - 230, Elsevier, 2013, DOI: 10.1016/j.proeng.2013.12.172. 
[9] Yücesu, H. S., Topgül, T., Çinar, C., \& Okur, M. (2006). Effect of ethanol-gasoline blends on engine performance and exhaust emissions in different compression ratios. Applied Thermal Engineering, 26(17-18), 2272-2278. doi:10.1016/j.applthermaleng.2006.03.006

[10] D. Turner, H. Xu, R. F. Cracknell, V. Natarajan, and X. Chen, "Combustion performance of bio-ethanol at various blend ratios in a gasoline direct injection engine," Fuel, vol. 90, no. 5, pp. 1999-2006, May 2011.

[11] Nakata, K., Utsumi, S., Ota, A., Kawatake, K., Kawai, T., \& Tsunooka, T. (2006). The Effect of Ethanol Fuel on a Spark Ignition Engine, (724).

[12] Yüksel, F., \& Yüksel, B. (2004). The use of ethanol-gasoline blend as a fuel in an SI engine. Renewable Energy, 29(7), 1181-1191. doi:10.1016/j.renene.2003.11.012

[13] Nakata, K., Utsumi, S., Ota, A., Kawatake, K., Kawai, T., \& Tsunooka, T. (2006). The Effect of Ethanol Fuel on a Spark Ignition Engine, (724).

[14] Al-Hasan, M. (2003). Effect of ethanol-unleaded gasoline blends on engine performance and exhaust emission. Energy Conversion and Management, 44(9), 1547-1561. doi:10.1016/S0196-8904(02)00166-8

[15] Khieralla, A. F., Baker, A., Ibrahim, A., Keir, L. A., Lino, S. M., \& Joeshp, V. N. (n.d.). Investigation of Ethanol / Gasoline Blends as Alternative Fuel for Spark Ignition Engine, 110.

[16] Dwyer, K., \& Carolina, N. (2008). Cost Effective Sustainable Fuels for Performance Vehicles, (724). 